Journal of Economic Theory 5 (3): 58-63, 2011

ISSN: 1994-8212

(C) Medwell Journals, 2011

\title{
Economical Valuation of River Services (Contingent Valuation and Cost-Benefit Approach)
}

\author{
Sadegh Bafandeh Imandoust \\ Department of Economics, Payame Noor University, Mashad, Iran
}

\begin{abstract}
One of the most important aspects of environmental economics is economic valuation. Natural resources such as rivers and rangelands are the most important factors for human and environmental survive. Less and discounting on natural resource values has been caused that the actual value of it to be showed less. For this reason, the broad objectives of this study is to determine the Direct Use Value (DUV) for river. Researcher believes that for some developing country like India Contingent Valuation (CVM) can be utilized for estimation of direct use value. A secondary aim of the study is to compare cost and benefit of Pune municipal plan for cleaning Pavana river, Pune, India. Results indicate that total dirct value of Pavana river is 5.9 milion rupees (59 lakh) per year (11.29 crore for 20 years) and it is greater than total cost of plan 8.94 crore ( 1 crore $=100$ lakh or 10 million Rs.). Thus, the application of economic value of rivers in production of environmental services and more investment for saving rivers is advised.
\end{abstract}

$\underline{\text { Key words: River services, economic valuation, direct use value, conting ent valuation, cost-benefit, production }}$

\section{INTRODUCTION}

In the last quarter of the 20th century, one of the major worries of the human kind has been deterioration in the quality of environment. Initially considered as a problem of industrial rich countries, environmental degradation is now recognized as an issue of concern in the developing world. Apart from subsistence conversion, rivers have yielded space to claims of developmental activities.

Pune is the 8th largest metropolis in India, the 2nd largest in the state of Maharashtra after Mumbai and the largest city in the Western Ghats with $3,446,330$ populations, 2010. Once the center of power of the Maratha Empire, it is situated $560 \mathrm{~m}$ above sea level on the Deccan plateau at the confluence of the Mula, Mutha and Pavana rivers. Pune city is the administrative capital of Pune district. Most of the industrial units are in PimpriChinchwad and on the banks of Pavana river. With over 4,000 industrial units in the large, medium and small sectors dotting its landscape, the sprawling PimpriChinchwad industrial belt is one of the largest of its kind in this part of the country and certainly boasts of some of the biggest names in the industry.

Take a look at the names that it is home to Tata Engineering, Bajaj Auto, Hindustan Antibiotic, The Finolex Group of Industries and a clutch of Swedish companies that made this twin city their home in the mid 60's including Sandvik Asia and Atlas Copco. The IT sector employs $>70,000$ people. Major software companies in Pune include Infosys, Persistent Systems, Wipro, TCS, Cognizant, Symantec, Tech Mahindra, Syntel and IBM global. Software giant Microsoft intends to set up a 700 crore (US\$155.4 million) project in Hinjewadi. The broad objectives of the study are:

- To determine the Direct Use Value (DUV) for Pavana river, Pune, India

- To make a comparative Cost-benefit analysis of Pavana action plan

Background: Many researches have recently been carried out in describing, distinguishing and categorizing biodiversity functions (WRI, 2005; Balmford et al., 2008; Markandya et al., 2008). Szabo (2010) provides an empirical research about increasing the validity of biodiversity.

Clayton and Mendelson (1993) estimated use values associated with the opportunity to view grizzly bears on the Mc Neil river in Alaska, employing the contingent valuation method to estimate a willingness to pay that ranged from $\$ 227-277$ person $^{-1}$ for a 4 days visit. Lerner and Poole (1999) estimated the defensive expenditures to protect water purification services of forested watershed of New Jersey forests as $\$ 55$ million. Barnhill (1999) attributed a portion of the economic impact of tourism along the Blue Ridge Parkway to the scenic beauty of adjacent forests. The study found that visitors spend 
$\$ 1.3$ billion in North Carolina and Virginia contiguous to the parkway which these expenditures generate $\$ 98$ million in tax revenues annually and that visitor spending directly, supports $>26500$ jobs. Loomis and Richardson (2000) calculated the carbon sequestration values of 42 million acres of roadless area on US National forests as $\$ 56$ ton $^{-1}, \$ 1$ billion annually and $\$ 26.7$ billion present value.

Anderson (2005) showed that even under uniform pricing, Ugandan's profit from gorilla tracking in the Bwindi impenetrable national park alone could have been increased by between USD 30,000 and 220,000 (depending on assumptions about social costs) based on data collected from a travel cost survey indicates that in 1997. A Cost-benefit analysis of the cleaning up the ganges is a comprehensive environmental economics research in India that is done by Markandeya and Murty (2000). This study is an example of using the methodology of standard Cost-benefit analysis for estimating the social benefits of an investment project for the preservation of environmental resources. Suitable extensions of standard methodology are made to deal with the special problems that arise in the valuation of benefits from the environmental resource, the Ganges in the present case. The cost of cleaning up of the Ganges has to be borne by the household and industries in the Gangetic basin according to the polluter pay principle.

The cost of the GAP is met by the Indian government. In addition to this cost as shown in this study, water polluting industries in the Gangetic basin are incurring a significant amount of cost for cleaning up the Ganges in the form of investment and operating cost of water pollution abatement. The estimates of benefits to households from cleaning up the Ganges made in this study can provide information to the government for designing appropriate instruments to charge the households for polluting the Ganges.

The cleaning up of the Ganges provides multiple benefits. The user and non-user benefit of cleaning the Ganges were estimated using the Contingent Valuation Method (CVM) of survey of households.

These benefits were described as people's Willingness To Pay (WTP) for cleaning the river. The CVM consisted of a carefully designed set of questionnaires to survey sample households in major cities in India. This survey had evoked unexpectedly good responses about the households; valuation of user and non-user benefits for an important water resource in India and provides a useful guide for similar future studies in India and abroad. The results of the non-user survey show that the average annual Willingness to Pay (WTP) for bathing quality water in the Ganga is
Rs. 558/household/annum. This yields an aggregate figure of Rs. 4873 million annum ${ }^{-1}$ for 8.733 million households from the urban literate population in 23 major cities. The average annual WTP for current (1995) quality in the Ganga is Rs. 193/ household/annum which aggregates to Rs. 1684 million annum ${ }^{-1}$. The value of non-user benefits for past (1985) quality that is the quality that existed before the GAP was initiated is Rs. 101/annum/household and works out to Rs. 852 million annum ${ }^{-1}$.

The results of the user survey show that the estimate of WTP for user benefits from bathing quality water is Rs. $581.59 /$ household/annum. It aggregates to Rs. 19.019 million annum ${ }^{-1}$ for 37,213 households in the target population of literate urban residents in the major cities in the states of Uttar Pradesh, Bihar and West Bengal who live within $0.5 \mathrm{~km}$ of the river. Willingness to pay for benefits from current (1995) water quality in the Ganga is Rs. 167.23/household/annum which works out to Rs. 5.5 million annum ${ }^{-1}$. Similarly, household WTP for the direct-user benefits for the water quality existing in 1985 is Rs. 93.28 annum $^{-1}$ which sums up to Rs. 3.1 million annum ${ }^{-1}$.

A comparison of these WTP estimates with those from other developing countries where the benefits of improvements in water quality levels have been assessed shows that the values obtained in this contingent valuation are broadly comparable.

This study has shown that Cost-benefit analysis can be applied with some success to river action program. The results are encouraging and relevant to policy makers in India. First, how one views the GAP depends on how one treats the distribution question. Without distribution weights, the benefits are largely to non-users and they are large enough to justify the project. With distribution weights, the project is even more justifiable but now it is on the grounds of the benefits it provides to low income users and on the benefits of income to unskilled workers employed in the construction sector.

Secondly, the marginal benefits of the project are much higher than the benefits of GAP (Ganga Action Plan). Finally, there are practical and sensible ways of making the programme financially sustainable viable. This study has presented some thoughts on this, although further research is clearly needed. I think this study is one of the most valuable research that has been done about environmental economic valuation in India.

\section{MATERIALS AND METHODS}

The Contingent Valuation Method (CVM) rests on the assumption that consumers can and will reveal their true willingness to pay for non-market goods, contingent 
Table 1: Participation in schemes

\begin{tabular}{lcr}
\hline Responses & Frequency & Percent \\
\hline Not participating and have polluted river & 65 & 21.31 \\
participate and have clean river & 238 & 78.03 \\
NR & 2 & 0.66 \\
Total & 305 & 100.00 \\
\hline
\end{tabular}

upon a hypothetical market (Mitchell and Carson, 1989). The total direct value of Pavana river has been assessed with utilize of CVM, so all direct users have been interviewed. The method utilized in this study is one of extended social Cost-benefit analysis where project cost and non-marketable benefit are quantified in monetary terms to the maximum extent possible. For an environmentally oriented project like the present study, many benefits are in this form.

There can be a variety of benefits from the improvement of quality of water in a fresh water body like the Pavana. These can be classified as user benefits and non-user benefits. As mentioned in the research, I focused on user benefits because researcher believed that non-user benefits are desirable for national project like Ganga river. In the case of Pavana river, we saw people living nearby the river are co-operative while the other people were not willing to pay for cleaning the river-water. Further research should be carried for finding non-user benefits (Table 1). The cost of Pavana action plan is borne by Pune municipal. For finding cost of Pavana action plan, the researcher interviewed additional city engineer in water supply and drainage department in Pune municipal. Moreover, Pavana action plan have been considered (Kunachgi, 2008).

\section{RESULTS}

Present value of user benefits for Pavana river: As is stated before, we did not consider non-user benefits in the research because non-user is plausible for important case like Ganga river. Ganga is important for all Indian people. Moreover, there could be some perceived benefits from knowing that a river of major religious significance is now cleaner. Every year many people visit the Ganga. But in case of Pavana situation is different. Thus, we calculated user benefits for Pavana.

For this purpose, we interviewed households, fishermen, farmers, Dhobi Ghat and bath taking people. We considered $1 \mathrm{~km}$ from each bank of river. Mean of WTP for all users estimated Rs. 17.73/family/month. In account of latest data, population of Pimpri-Chinchwad (industrial area of Pune) is $10,06,417$ in the $170 \mathrm{~km}^{2}$ area. Thus, density can be estimated as follows:

$$
\text { Density }\left(\mathrm{km}^{2}\right)=1006417 / 170=5920
$$

Pavana length is $11.5 \mathrm{~km}$ inside the city. So, total sampling area is $23 \mathrm{~km}^{2}(11.5 \times 2)$. Total user population can be estimated easily.

\section{$23 \times 5920=1,36,160$ total user population}

As per of census 2010, household size is 4.9; therefore total families in this case can be calculated as, $136,160 / 4.9=27,787.7$ households.

If we multiply this to Rs. 17.73 aggregate monthly benefits will emerge. Then yearly amount also will be $17.73 \times(27,787.7)=4,92,676$. Total WTP per month 4 , $92,676 \times 12=59,12,122$ is total user benefit per year. As can be seen from above total user benefit per year is about Rs. 59 lakh.

Discount rate: Projects involving stream of benefits and costs over a long period of time need to be evaluated after necessary discounting. This step is necessary as the benefits and costs accruing in different periods are not comparable in terms of their opportunity values and hence, they are not even additive. Discounting the benefits and costs over the time requires a value for the discount rate. In this analysis, the bank rate is utilized as the rate of discount. The bank rate in the latest Reserve Bank of India bulletin is 6\%.

Period of benefits: Although, benefits of clean Pavana river will continue for many years, we consider 20 years period. Moreover, we increase total yearly benefits $5 \%$ annum $^{-1}$ in account of population growth. Thus, the present value of total user benefits upto 2025 will work out to about Rs. 11.29 crore.

\begin{tabular}{ll} 
Aggregate WTP (user benefits) & \\
\hline Density $\left(\mathrm{km}^{2}\right)$ in Pimpri-Chinchwad & 5,920 persons \\
Total user population & $1,36,160$ person \\
Number of families in research area & $27,787.7$ \\
Total monthly WTP & Rs. $4,92,676 /-$ \\
User benefits per year say Rs. 59 lakh & Rs. $59,12,122 /-$ \\
Rate of discount & $6 \%$ \\
Aggregate present value for user benefits & Rs. 11.29 crore \\
\hline
\end{tabular}

Present value of costs: As stated before, researcher interviewed Head of Water Supply Department in Pune municipal for finding cost of Pavana action plan. During the interviews, we mentioned different items of Pavana action plan.

Construction of Sewage Treatment Plants (STP) is necessary for each city and cleaning the Pavana river. But the respondents believed that its PCMC's duty. Thus, we did not consider STP cost in the Cost-benefit analysis. Other schemes included are as follows. Different works have been completed like: 
- Construction of Nirmalya Kundi (burning corpse) at various locations, cost of these was Rs. 10 lakh

- Constructions of Dhobi Ghat at various places along with small treatment plant. The cost of constructions for these three places also announced Rs. 10 lakh

- Construction of Smashan Kundies at various places where the smashan bhoomis located on the bank of river at the cost of Rs. 60 lakh

- Fencing near river area where there is pathway towards river to avoid pollution by non-point source like animal and vehicle washing (costing Rs. 3 crore)

- Erection/installation of various sizes of screen bars at various levels on major 11 nallas (creeks) to prevent floating material reaching Pavana river. This has been done at the cost of Rs. 7.5 lakh

- Development of boat club near Thergaon, costing Rs. 50 lakh

- Desalting of river bed with the help of College of Military Engineering and private agency, costing Rs. 10 lakh

Total amount of Rs. 4.47 crore in spent on these seven items. Clearly every year, we need some money for operation and maintenance. After studying other research and in consolation with PMC city engineer, $5 \%$ of total cost is considered as maintenance and operation cost per year. Normally every year, this cost will increase because of inflation and other factors. On the other hand, during Cost-benefit process we should discount future amounts for cost. Therefore, it was decided to calculate this cost as $5 \%$ for each year without any regulation. Thus, maintenance and operation cost can be estimated as follows:

$$
4.47 \times 5 \%=\text { Rs. } 0.2234 \text { crore year }^{-1}
$$

Total maintenance and operation cost for 20 years $=0.2235 \times 20=$ Rs. 4.47 crore. Thus, the total cost of plan is $4.47+4.47=$ Rs. 8.94 crore. Finally, NPV is as follows:

$$
\begin{aligned}
\text { NPV }= & \text { Present value of benefits - } \\
& \text { Present value of cost }
\end{aligned}
$$$$
\mathrm{NPV}=11.29-8.94=\text { Rs. } 2.35 \text { crore }
$$

Summary of CBA

\begin{tabular}{ll} 
Present value of benefits & Rs. 11.29 crore \\
Present value of costs & Rs. 8.94 crore \\
Net present value & Rs. 2.35 crore \\
\hline
\end{tabular}

Second scenario: It is clear that for improving of water quality in Pavana, more efforts should be made. For example during the study, we saw many Dhobi Ghat persons, they are using soap and detergents for washing clothes. As we observed, there was no water treatment provision.

PCMC or other organization should make some provision for some special place with piped water and small treatment plant. It is not necessarily to be near the river. We can make this provision at other places especially near slum area. When we asked Dobi Ghat women whether they knew that their work is harmful for river, all of them said yes. They are ready to use special place but they will not pay money for this service. There are about 150-200 professional washing persons. Therefore, at least three more Dhobi Ghat should be constructed at the cost of Rs. 10 lakh. Moreover, we need at least one clean and appropriate place for holy bath near Morya Gosavi Temple. For this purpose, one small diversion from Pavana river needs to be constructed as people want to use river water. Then at the end of this diversion nalla, small treatment plant should be constructed and after treatment, clean water should be let into the river. This is not very complicated and difficult plan; it can be constructed at Rs. 30 lakh $(\mathrm{MO}$ cost $=$ 40 lakh $\times 5 \% \times 20$ years $=$ Rs. 40 lakh or Rs. 0.4 crore). Also, one-time complete cleaning of bed and around the river is necessary with a board to create awareness about pollution; the board should indicate the motto keep our river clean. It will cost at least Rs. 1 crore.

Cost benefit for second scenario

Present value of user benefits

Present value of cost in phase 1

Cost of second scenario:

Three Dhobi Ghats

One place for holy bath

Cleaning river bed and around

and awareness board

Maintenance and operation

Total cost of phase- 2

Total cost of phase 1 and 2

NPV (11.94 less 10.74)

Rs. 11.29 crore
Rs. 9.14 crore
Rs. 0.1 crore
Rs. 0.3 crore
Rs. 1.0 crore
Rs. 0.4 crore
Rs. 1.8 crore
Rs. 10.74 crore
Rs. 0.55 crore

Third scenario: The researcher has done the survey of river in order to identify the polluting spots and the survey revealed that there are total 87 locations of pollution through which sewage water is joining to river. Out of 87 locations are 11 main nallas joining river. These nallas are carrying industrial and domestic waste water. About 7 out of 11 nalla are carrying both industrial and domestic waste water. Parks were designed and constructed along two nalls (Mahavir park and Premlok park). It was supposed to utilize nalla water for irrigating these two parks. But the researcher himself visited nalla parks and found water from the nallas highly polluted and unfit for irrigation. Thus, gardeners are using corporation water for irrigation. Moreover, the corporator also has 
confessed these two parks are not maintained properly. Two small treatment works for these two nalla parks are suggested. If small treatment plant is constructed near the Nalla park then the treated water can be used for irrigation. One good example for nalla park is Osho Garden in Pune city also called Zen Garden (2), Japanese type of garden. Cost of the two small treatment plants for Mahavir and Premlok is estimated at Rs. 0.25 crore each and therefore, Rs. 0.5 crore for both these parks. For compensating this cost, we can consider Rs. 2 as entrance fee per person. It is not a big amount and we have same entrance fee in Pune city (Tathawade park for instance). If everyday 500 persons visit these two parks in 300 working days a year, net present value of this scheme can be estimated as follows is discount rate $=6 \%$, period of scheme $=20$ years, Rs. 1,000 day $^{-1}$ income for each park and Rs. 103 lakh present value of income for 20 years (one park). Following data represents summarized CBR for 3rd scenario. Two former phases are also considered in the final calculation. Like previous section, we considered $5 \%$ of the initial cost for maintenance and operation.

Maintenance and operation cost $=0.05 \times 0.5 \times 20=$ Rs. 0.5 crore

CBA for 3rd scenario

\begin{tabular}{ll}
\hline Benefits & \\
Present value of user benefits & Rs. 11.29 crore \\
Present value for entrance fees & Rs. 2.06 crore \\
Aggregate benefits & Rs. 13.35 crore \\
Cost & \\
Total cost of phase 1 and 2 & Rs. 10.74 crore \\
Nalla treatment plant including operation & Rs. 1.00 crore \\
and maintenance for 20 years & \\
Aggregate cost & Rs. 11.74 crore \\
NPV & Rs. 1.61 crore \\
\hline
\end{tabular}

On this basis, it can be concluded the construction of these three plants will prove very useful for society and rational from economical point of view.

\section{CONCLUSION}

Aggregate present value of direct use benefits for the period of 20 years and 6\% discount rate is Rs. 11.29 crore. Three scenarios were designed by researcher for improving in Pavana river. First scenario included 7 items like construction of Nirmalya Kundli, washing place, Smashan Kundies fencing and so on. Total cost of 1 st scenario estimated about Rs. 4.47 crore. Present value of cost including operation and maintenance for 20 years and $6 \%$ discount rate is estimated at Rs. 8.94 crore. Thus, net present value of 1 st scenario was Rs. 2.35 crore. In 2nd scenario, we considered more items including cleaning river bed constructing one place for holy bath and three more Dobi Ghats with small treatment plant. The cost of 2 nd scenario was Rs. 1.8 crore. NPV for 2 nd scenario was Rs. 0.55 crore.

In 3rd scenario, we considered small treatment for using nalla water for gardening. Entrance fee is considered at Rs. 2 person ${ }^{-1}$. Net Present Value (NPV) of the 3rd scenario is estimated at Rs. 1.61 crore. On this basis of Cost-benefit analyses, it can be concluded the construction of these three plants will prove very useful for society and rational from economical point of view.

\section{ACKNOWLEDGEMENTS}

This study is part of research that was submitted as $\mathrm{PhD}$ thesis in Pune University under supervising Professor S.N. Gadam, Director of Education and Development Research Centre, Pune (Former reader in Economics, Gokhale Institute of Politics and Economics, Pune).

\section{REFERENCES}

Anderson, P., 2005. Potential monopoly rents from international wildlife tourism: An example from Uganda's gorilla tourism. Eastern Afr. Social Sci. Res. Rev., 21: 1-18.

Balmford, A., A. Rodrigues, M. Walpole, P.T. Brink, M. Kettunen, L. Braat and R. De Groot, 2008. Review on the economics of biodiversity loss: Scoping the science. DG Environment, European Commission, http://citeseerx.ist.psu.edu/viewdoc/download?doi $=10.1 .1 .156 .2796 \& \mathrm{rep}=$ repl \&type $=$ pdf.

Barnhill, T., 1999. Our green is our gold: The economic benefits of national forests for southern Appalachian communities. A Forest Link Report of the Southern Appalachian Forest Coalition. Southern Appalachian Forest Coalition.

Clayton, C. and R. Mendelson, 1993. The value of watchable wildlife: A case study of Mc Neil River. J. Environ. Manage., 39: 101-106.

Kunachgi, N.R., 2008. Pavana Action Plan. PCMC, Pimpri Chinchwad, Maharashtra.

Lerner, S. and W. Poole, 1999. The Economic Benefits of Parks and Open Space: How Land Conservation Helps Communities Grow Smart and Protect Bottom Line. The Trust for Public Land, San Francisco, California.

Loomis, J. and R. Richardson, 2000. Economic Values of Protecting Areas in the United States. Wilderness Society, Washington, DC. 
Markandeya, A. and M.N. Murty, 2000. A Cost-Benefit Analysis of the Ganga Action Plan: Cleaning-up the Ganges. Oxford University Press, New Delhi, pp: 116-137.

Markandya, A., P.A.L.D. Nunes, I. Brauer, P.T. Brink, O. Kuik and M. Rayment, 2008. Review on the economics of biodiversity loss-Economic analysis and synthesis. Final Report for the European Commission, Venice, Italy, pp: 140.

Mitchell, R.G. and R.T. Carson, 1989. Using Surveys to Value Public Goods: The Contingent Valuation Method (Resources for the Future). RFF Press, Washington, DC.
Szabo, Z., 2010. Increasing the validity of valuing biodiversity: Reducing protest responses by deliberative monetary valuation. Proceedings of the 12th Annual BIOECON Conference From the Wealth of Nations to the Wealth of Nature: Rethinking Economic Growth, Sept. 27-28, Centro Culturale Don Orione Artigianelli, Venice, Italy, pp: $1-15$.

WRI, 2005. Millennium Ecosystem Assessment: Ecosystems and Human Well-being-Biodiversity Synthesis. World Resources Institute, Washington, DC. 